\title{
Research Regarding the Simultaneous Control of the Pathogens on Tomatoes Crops under High Plastic Tunnels
}

\author{
Gabriela ȘOVĂREL*, Marcel COSTACHE, Ana - Emilia CENUȘ̆ \\ Plant protection laboratory, Research - Development Institute for Vegetable and Flower Growing Vidra, Ilfov, \\ Romania \\ *)Corresponding author, e-mail: gabriela_sovarel@yahoo.com \\ BulletinUASVM Horticulture 74(1) / 2017 \\ Print ISSN 1843-5254, Electronic ISSN 1843-5394 \\ DOI:10.15835/buasvmcn-hort:12308
}

\begin{abstract}
In Romania the most important pathogens on tomatoes crops are Alternaria porri f.sp. solani, Botrytis cinerea, Fulvia fulva, Phytophthora infestans and Erysiphe sp. During period of vegetation, the attacks of mentioned pathogens are frequently overlapping. For simultaneously control of pathogens were used some combination with different active substances (chlorothalonil 500g/l, iprodione $500 \mathrm{~g} / \mathrm{l}$, fenhexamid $500 \mathrm{~g} / \mathrm{l}$, thiophanate methyl 500g/l, metiram 80\%, dimethomorph 9\%, mancozeb 60\%, difenoconazole $250 \mathrm{~g} / \mathrm{l}$, fenamidone $75 \mathrm{~g} / \mathrm{l}$, propamocarb HCL $375 \mathrm{~g} / \mathrm{l}$. The best results for controlling Alternaria porri f.sp. solani, Botrytis cinerea and Fulvia fulva are metiram $80 \% 0.2 \%$ + thiophanate methyl $500 \mathrm{~g} / \mathrm{l} 0.14 \%$ with $93.5 \%$ efficacy. In the untreated check the degree of attack was 78.6\% (44.3\% A. solani, 7.0\% B. cinerea and 27.3\% F. Fulva). For controlling Phytophthora infestans, Erysiphe sp. and Fulvia fulva (fenamidone 75g/l + propamocarb HCL $375 \mathrm{~g} / \mathrm{l}$ ) $\quad 0.2 \%$ + difenoconazole $250 \mathrm{~g} / \mathrm{l} 0.05 \%$ with $94.5 \%$ efficacy. In the untreated check the degree of attack is $81.2 \%$ (38.4\% P. infestans, $27.4 \%$ Erysiphe sp. , 15.4\% F. fulva).
\end{abstract}

Keywords: pathogens control, plastic tunnels, tomatoes

\section{Introduction}

In Romania the most important pathogens on tomatoes crops are: Alternaria porri f.sp. solani (early blight) (Tomescu, 2003), Botrytis cinerea (grey mould) (Snowdwn A, 2010), Fulvia fulva (leaf mold), Phytophthora infestans (late blight) (Corbu, 2014) and Erysiphe sp. (powdery mildew).

\section{Aims and objectives}

During period of vegetation, the attack of mentioned pathogens are frequently overlapping. The aim of this research is to identify fungicide combinations for simultaneously control of pathogens attack.

\section{Materials and methods}

The research were realised on 2015, under high plastic tunnels with multiple possibility of ventilation, using tomato hybrid Prekos $\mathrm{F}_{1}$. Planting date 20.06.2015, density 38000 plants/ ha.

For controlling Alternaria porri f. sp. solani, Botrytis cinerea and Fulvia fulva were used 7 variants: 1 . chlorothalonil $500 \mathrm{~g} / \mathrm{l} 0.2 \%+$ iprodione $500 \mathrm{~g} / \mathrm{l} 0.1 \%$; 2. chlorothalonil 500g/l $0.2 \%+$ fenhexamid $500 \mathrm{~g} / \mathrm{l} \quad 0.08 \%$; 3. chlorothalonil $500 \mathrm{~g} / \mathrm{l} \quad 0.2 \%$ + thiophanate methyl $500 \mathrm{~g} / \mathrm{l}$ $0.14 \%$; 4. metiram $80 \% 0.2 \%$ + iprodione $500 \mathrm{~g} / \mathrm{l}$ $0.1 \%$; 5. metiram $80 \% \quad 0.2 \%+$ fenhexamid 500 g/l $0.08 \%$; 6. metiram $80 \% \quad 0.2 \%$ + thiophanate methyl 500g/l 0.14\%; 7. Untreated check.

For controling Phytophthora infestans, Erysiphe sp. and Fulvia fulva pathogens were used 5 variants: 1 . (dimethomorph $9 \%+$ mancozeb $60 \%) 0.2 \%+$ difenoconazole $250 \mathrm{~g} / \mathrm{l}$ 0.05\%; 2. (dimethomorph $9 \%+$ mancozeb 60\%) 
Tab. 1. Efficacy of some fungicides combination for simultaneously control of pathogens Alternaria solani, Botrytis cinerea and Fulvia fulva on tomatoes

\begin{tabular}{|c|c|c|c|c|c|c|c|}
\hline \multirow{2}{*}{ Variant } & \multirow{2}{*}{$\begin{array}{c}\text { Concentration } \\
(\%)\end{array}$} & \multicolumn{4}{|c|}{ Degree of attack (\%) } & \multirow{2}{*}{$\begin{array}{c}\text { Efficacy } \\
(\%)\end{array}$} & \multirow{2}{*}{$\begin{array}{l}\text { Yield } \\
\text { (t/ha) }\end{array}$} \\
\hline & & A. solani & B.cinerea & F. fulva & Total & & \\
\hline 1 & $0.2+0.1$ & 4.0 & 1.7 & 0 & 5.7 & 92.7 & 50.9 \\
\hline 2 & $0.2+0.08$ & 5.7 & 1.0 & 3.8 & 10.5 & 86.6 & 50.4 \\
\hline 3 & $0.2+0.14$ & 4.7 & 1.1 & 1.8 & 7.6 & 90.3 & 50.6 \\
\hline 4 & $0.2+0.1$ & 3,1 & 1.1 & 3.1 & 7.3 & 90.7 & 48.8 \\
\hline 5 & $0.2+0.08$ & 6.3 & 0 & 3.9 & 10.2 & 87.0 & 48.5 \\
\hline 6 & $0.2+0.14$ & 2.5 & 0 & 2.6 & 5.1 & 93.5 & 49.3 \\
\hline 7 & - & 44.3 & 7.0 & 273 & 78.6 & - & 45.3 \\
\hline
\end{tabular}

Tab. 2. Efficacy of some fungicides combinations for simultaneously control of pathogens Phytophthora infestans, Erysiphe sp. and Fulvia fulva on tomatoes

\begin{tabular}{|c|c|c|c|c|c|c|c|}
\hline \multirow{2}{*}{ Variant } & \multirow{2}{*}{$\begin{array}{c}\text { Concentration } \\
(\%)\end{array}$} & \multicolumn{4}{|c|}{ Degree of attack (\%) } & \multirow{2}{*}{$\begin{array}{c}\text { Efficacy } \\
(\%)\end{array}$} & \multirow{2}{*}{$\begin{array}{l}\text { Yield } \\
\text { (t/ha) }\end{array}$} \\
\hline & & Ph. infestans & Erysiphe sp. & F. fulva & Total & & \\
\hline 1 & $0.2+0.05$ & 3.5 & 1.4 & 0 & 4.9 & 94.0 & 49.9 \\
\hline 2 & $0.2+0.14$ & 4.9 & 3.2 & 0.3 & 8.4 & 89.6 & 49.8 \\
\hline 3 & $0.2+0.05$ & 3.1 & 1.0 & 0.4 & 4.5 & 94.5 & 51.8 \\
\hline 4 & $0.2+0.14$ & 4.5 & 3.8 & 1.4 & 9.7 & 88.0 & 51.0 \\
\hline 5 & - & 38.4 & 27.4 & 15.4 & 81.2 & - & 44.7 \\
\hline
\end{tabular}

$0.2 \%$ + thiophanate methyl $500 \mathrm{~g} / \mathrm{l} 0.14 \% ; 3$. (fenamidone $75 \mathrm{~g} / \mathrm{l}+$ propamocarb HCL 375 $\mathrm{g} / \mathrm{l}) \quad 0.2 \%+$ difenoconazole $250 \mathrm{~g} / \mathrm{l} 0.05 \% ; 4$. (fenamidone $75 \mathrm{~g} / \mathrm{l}+$ propamocarb HCL $375 \mathrm{~g} / \mathrm{l}$ ) $0.2 \%$ + thiophanate methyl $500 \mathrm{~g} / \mathrm{l} 0.14 \%$ and 5 . Untreated check.

Were made six applications, at 10 days intervals, during the growing season. First application was made at beginning infection risk.

There were made assessments (10 days after last application) on the leaves regarding the frequency (F \%) and severity (S \%) of pathogen attack and were calculated the attack degree (DA $\%$ ) and efficacy (E \%). The degree of attack was calculated with formula (F\% x S \%) /100 and efficacy with formula (DA untreated \% - DA treated \%) x 100/DA untreated.

\section{Results and discusions}

The best efficacy for controlling Alternaria porri f.sp. solani, Botrytis cinerea and Fulvia fulva were obtained with the variants: 1 . chlorothalonil $500 \mathrm{~g} / \mathrm{l} \quad 0.2 \%$ + iprodione $500 \mathrm{~g} / \mathrm{l} \quad 0.1 \%$ (92.7\%) and 6 . metiram $80 \% 0.2 \%+$ thiophanate methyl $500 \mathrm{~g} / \mathrm{l} 0.14 \%$ (93.5\%; tab. 1).
For controling Phytophthora infestans, Erysiphe sp. and Fulvia fulva the best results were obtained from the following variants: 3. (fenamidone $75 \mathrm{~g} / \mathrm{l}+$ propamocarb HCL $375 \mathrm{~g} / \mathrm{l}$ ) $0.2 \%+$ difenoconazole $250 \mathrm{~g} / 10.05 \%$ and 1 . (dimethomorph $9 \%+$ mancozeb $60 \%$ ) $0.2 \%+$ difenoconazole $250 \mathrm{~g} / \mathrm{l} 0.05 \%$, with $94.5 \%$ and respectively $94.0 \%$ efficacy (tab. 2).

\section{Conclusion}

There were identified several product combinations which provide a good control of main pathogens on tomatoes under protected crops.

Very good efficacy for controlling Alternaria porri f.sp. solani, Botrytis cinerea and Fulvia fulva are metiram $80 \% 0.2 \%$ + thiophanate methyl $500 \mathrm{~g} / \mathrm{l} 0.14 \%$ and chlorothalonil 500g/l $0.2 \%+$ iprodione $500 \mathrm{~g} / \mathrm{l} 0.1 \%$.

For controling Phytophthora infestans, Erysiphe sp. and Fulvia fulva the best results were obtained from the following combinations:(fenamidone $75 \mathrm{~g} / \mathrm{l}+$ propamocarb HCL $375 \mathrm{~g} / \mathrm{l}) 0.2 \%$ + difenoconazole $250 \mathrm{~g} / \mathrm{l} 0.05 \%$ and (dimethomorph $9 \%+$ mancozeb 60\%) $0.2 \%$ + difenoconazole $250 \mathrm{~g} / \mathrm{l}$ $0.05 \%$. 


\section{REFERENCES}

1. Corbu1 G, Jurcoane S, Lagunovschi-Luchian V (2014) Techniques of companion planting for improving fruit quality and the protection against diseases and pests in tomato culture. Scientific Papers. Series B, Horticulture. vol. LVIII, print ISSN 2285-5653.
2. Snowden A (2010). Post-harvest diseases and disorders of fruits and vegetables: volume 2. Vegetables. Manson publishing Ltd.

3. Tomescu A, Negru G (2003). An overview on fungal diseases and pests on the field tomato crops in Romania. ISHS Acta Horticulturae 613: VIII International symposium on the processing tomato:259-266. 